\title{
Bioaccumulation of heavy metals and histopathological changes in muscles of common carp (Cyprinus carpio L.) in the Iraqi rivers
}

\author{
M.M.T. Jaber', Z.M. Al-Jumaa², S.K. Al-Taee², H.H. Nahi ${ }^{3}$ M.O. Al-Hamdany, M.A. Al-Salh, \\ B. Al-Mayahi ${ }^{4}$
}
${ }^{1}$ Forensic DNA for research and training, Al-Nahrain University, ${ }^{2}$ College of Veterinary Medicine, Mosul University, ${ }^{3}$ College of Veterinary Medicine, Al-Qasim Green University, ${ }^{4}$ Faculty of Science, Department of Environment, University of Kufa, Iraq

\section{Article information}

\section{Article history:}

Received February 28, 2020

Accepted July 13, 2020

Available online February 15, 2021

\section{Keywords:}

Cyprinus carpio

Heavy metal accumulation

Histopathological changes

Muscle

\section{Correspondence:}

S.K. Al-Taee

shahbaa_khal@uomosul.edu.iq

\begin{abstract}
The aim of this study is to evaluate the contamination status of Iraqi rivers in the north of the Tigris river (Tikrit city) and the middle region of Euphrates (Babylon Governorate). In this study $\mathrm{As}, \mathrm{Zn}, \mathrm{Fe}, \mathrm{Pb}$, and $\mathrm{Cu}$ in the muscle tissue of carp fish were measured. The results show that the concentration of arsenic in the fish muscles in the middle region was 425.05 ppm higher than its concentration of about $192.25 \mathrm{ppm}$ in fish muscle in the Tigris river with statistical significance $(\mathrm{P} \leq 0.05)$. Which it causes histopathological changes characterized by Zenker's necrosis in skeletal muscle and infiltration of inflammatory cells with edema additional to edematous dermatitis. Other heavy metals in fish muscle were less than in fish muscles which agreement with the international legislation limits. Also, there were positive correlation ships between $\mathrm{Zn}$ and $\mathrm{Pb}$ and between $\mathrm{Cu}$ and $\mathrm{Zn}$. While negative correlation has been detected between arsenic and both $\mathrm{Pb}$ and $\mathrm{Zn}$. This study is concluded that the accumulation of heavy metals causes histological changes in fish muscle provides an opportunity to assess fish health as well as information on possible health hazards coming from their environment.
\end{abstract}

DOI: 10.33899/ijvs.2020.126748.1368, (C2021, College of Veterinary Medicine, University of Mosul.

This is an open access article under the CC BY 4.0 license (http://creativecommons.org/licenses/by/4.0/).

\section{Introduction}

Recently, the fish industry is highly developed to be in compliance with population growth and being an important protein source for humans (1). The alteration of the aquatic environment mainly temperature and water quality are the most important factors affecting living aquatic organisms as Tilapia fish and Cyprinus carpio (2,3). Metal pollution which enter the aquatic environment from natural or Industrial waste sources, is one of the five main kind toxic pollutants in the water due to its physical and chemical properties, as well as low degradation and the possibility of its interaction with the organic materials in the aquatic environment and forming more toxic compounds and may have ability to accumulation in the tissue of organisms (4-6). Fish is a vital indicator of pollution in the aquatic environment and is used to study the toxic effect of many pollutants through the study of fish behavior, biochemical and histological changes as well as metal bioaccumulation (6-8). There are many studies about the metal accumulation in internal organs, liver consider main organ for metal and toxic detoxification which may show histopathological changes as a result of metals bioaccumulation $(9,10)$. Also $\mathrm{Al}$-Taee referred an alteration in fish behavior as well as histopathological changes in both liver and kidney of Cyprinus carpio as a result of cadmium toxicity also changes in fish enzyme activity and refer to cadmium accumulation in gill, liver and kidney (11). Metal accumulation may affected public health (12) and histological changes in fish muscles are very rare, so the aim of this study was determined the concentration of bioaccumulation of heavy metals in muscle of Cyprinus carpi and study 
histopathological changes in muscle with determine the inter-correlation between the heavy metals.

\section{Materials and methods}

One hundred and fifty carp fish $2 \mathrm{~kg} \pm 50 \mathrm{~g}$ were collected from floating cage from Tiger river (Tikrit city) in north and from Euphrates river in Middle regions (Babylon government) in Iraq. Study carried out in the autumn and spring in 2018. Fish were anesthetized according to (13) and large dorsal muscle behind head were dissected and one part of it were fixed in buffer formalin $10 \%$ for histopathological evaluation, paraffin embedding technique for histological preparation were used and stained with hematoxylin and eosin (14). Other part of muscle was prepared for evaluation of metal accumulation $\mathrm{As}, \mathrm{Pb}, \mathrm{Cu}, \mathrm{Zn}$, and Fe which is keep in foil paper in freezing temperature $-5^{\circ} \mathrm{C}$. According to (15) method $\mathrm{HNO}_{3} 65 \%$ were added to $0.1 \mathrm{~g}$ of muscle and digested by electrical homogenizer400 circle/min then the sample kept in water bath at $70 \mathrm{C}^{\circ}$ for overnight and then the kept in room temperature for 72 hours to complete muscle digestion (15), the metal evaluation in muscle solution were estimated by Atomic absorption spectrophotometers (AAS) in forensic DNA for research and training department lab, Al-Nahrain University/ Bagdad.

\section{Statistical Analysis}

Statistical Analysis was done by used CRD and to indicate significant differences in metal concentration in muscle tissue of fish used Duncan's multiple range test additional Pearson's correlation coefficients between metals concentration means was be used.

\section{Results}

\section{Clinical signs}

Fish were expressed lethargy, illness, abnormal swimming with loss appetite decrease body weight without showing any gross lesions.

\section{Metals bioaccumulation}

The metals concentrated in the fish muscle varied according to geographical region so the results of these study revealed that As was highly significant accumulative concentration in muscle of both fish in the Euphrates river in the middle region and Tigris River in northern region in Iraq which are $425.05,192.25 \mathrm{ppm}$ respectively than control group (international legislation limits) , others metals Fe, Zn, $\mathrm{Cu}$ were highly significant accumulative concentration in muscle of fish in the Euphrates river in the Middle region than in north region, all they are less than control group except the accumulative concentration of $\mathrm{Pb}$ which is highly significant $(\mathrm{P} \leq 0.05)$ than control and middle region (Table 1).

\section{Inter -metal correlation between heavy metals}

The result of correlation between means of concentration of the metals in skeletal muscles revealed in (Table 2). Strong positive correlation link between lead and zinc also between copper and zinc. Also, strong negative correlation link between arsenic with both lead and zinc. No significant correlation was observed between other metals.

Table 1: Bioaccumulation of metals (ppm) in muscle tissue and according to geographical distribution (Mean \pm SD)

\begin{tabular}{ccccccc}
\hline & \multicolumn{2}{c}{ Middle region } & \multicolumn{2}{c}{ North region } & \multicolumn{2}{c}{ Control } \\
\cline { 2 - 7 } & Mean & SD & Mean & SD & Mean & SD \\
\hline $\mathrm{Fe}$ & $100 \mathrm{a}$ & 0.09 & $23.9 \mathrm{c}$ & 0.82 & $60.65 \mathrm{~b}$ & 0.90 \\
$\mathrm{~Pb}$ & $0.08 \mathrm{~b}$ & 0.005 & $1.27 \mathrm{a}$ & 0.08 & $0.00 \mathrm{c}$ & 0.00 \\
$\mathrm{Zn}$ & $100 \mathrm{a}$ & 0.1 & $0.21 \mathrm{c}$ & 0.00 & $6.80 \mathrm{~b}$ & 1.47 \\
$\mathrm{Cu}$ & $30.0 \mathrm{a}$ & 0.8 & $0.34 \mathrm{c}$ & 0.03 & $20.38 \mathrm{~b}$ & 1.19 \\
$\mathrm{As}$ & $1.00 \mathrm{c}$ & 0.005 & $192.25 \mathrm{~b}$ & 6.54 & $425.05 \mathrm{a}$ & 4.54 \\
\hline
\end{tabular}

Different litters mean there were significant variation at $\mathrm{P} \leq 0.05$.

Table 2: Pearson's Correlation coefficients values between the metals in the skeletal muscles of Cyprinus carpio

\begin{tabular}{ccccc}
\hline & $\mathrm{Pb}$ & $\mathrm{Zn}$ & $\mathrm{Cu}$ & $\mathrm{As}$ \\
\hline $\mathrm{Pb}$ & 100 & & & \\
$\mathrm{Zn}$ & $0.74^{* *}$ & 1.00 & & \\
$\mathrm{Cu}$ & $0.17^{\mathrm{ns}}$ & $0.79^{* *}$ & 1.00 & \\
$\mathrm{As}$ & $-0.99^{* *}$ & $-0.80^{* *}$ & $-0.26^{\mathrm{ns}}$ & 1.00 \\
\hline$*$ Significant at $(\mathrm{P}<0.001), \mathrm{ns}=$ not significant.
\end{tabular}

\section{Histopathological examination}

Microscopic examination of muscle of carp in both regions and which have high concentrations of As 425.05 ppm revealed histopathological changes characterized by Zenker's necrosis in white skeletal muscles, edema and lymphosytic myositis (Figures 1 and 2) with elongation of muscle bundles (Figure 3), the histopathological examination of skin (dermis layer) exhibited edema with dermatitis (Figure 4).

\section{Discussion}

Many problems cause damage to aquatic environment, one of them is the pollution which results from urban, agriculture and industrial waste, also non-essential metals as cadmium and lead cause toxicity to aquatic animal even at low concentration additional to essential metals consider toxic when it takes at high levels concentration, all these pollutants metals cause damage to aquaculture and aquatic animals $(16,17)$. The results of present study shows that middle region in Euphrates river are more contaminated than the northern region of the Tigris these may be result from decline water river level which lead to concentration the organic and 
inorganic materials, also metals enter river by waters in the upper and middle parts of river additionally that pollution may originate from chemicals factory, power plant factory and leather. These reasons have been aggregate with idea of Curlik and Matusova (18). Fish is a good biomarker for pollutants in the aquatic environment because heavy metals accumulated in the organs as liver, kidney, gill also in the muscle which is more important because fish consider main diet for human as a result continuing high levels of protein, omega three with low concentration of cholesterol so it necessary to investigated and study the heavy metals accumulative in fish (19).

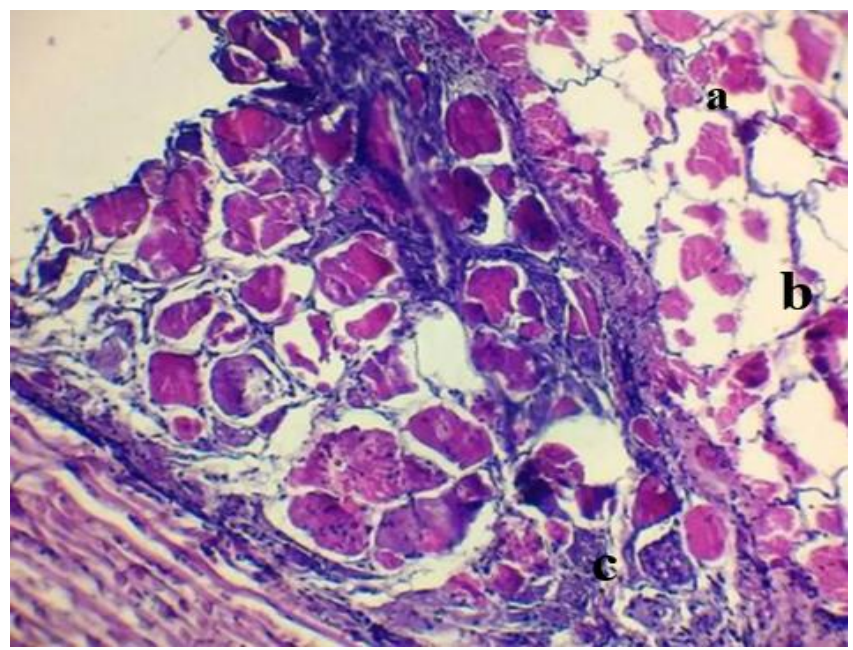

Figure 1: Microscopic examination of muscle in fish from Euphrates region with high accumulative concentration of As revealed zenker's necrosis (a), edema (b) and lymphosytic myositis (c). 10*1.2x, H\&E.

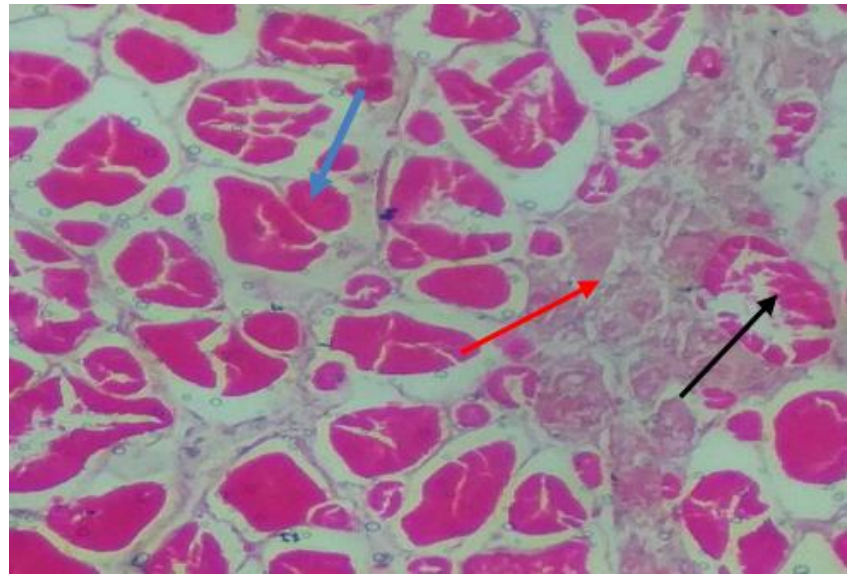

Figure 2: Microscopic examination of muscle in fish from Euphrates region with high accumulative concentration of As revealed sever shortening of muscle bandle (blue row) zenker's necrosis (black row) and edema (red row). 10*2x, Gomor's stain.

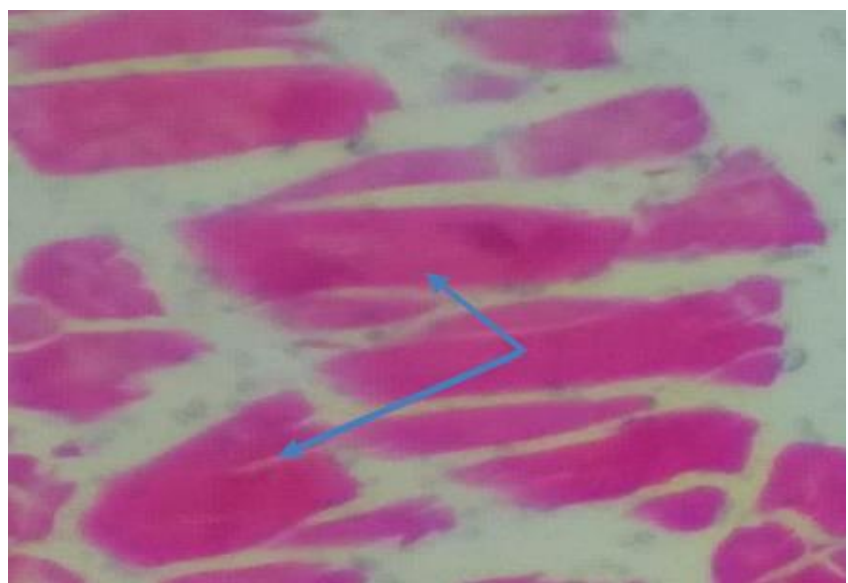

Figure 3: Microscopic examination of muscle in fish from Euphrates region with high accumulative concentration of As revealed elongation muscle bundles (blue row). 4*1x, Gomor's stain.

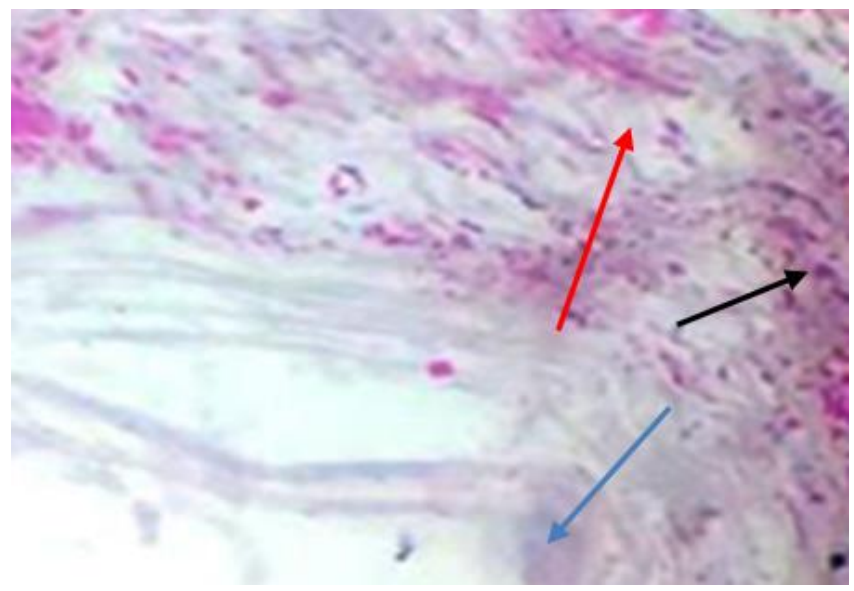

Figure 4: Microscopic examination of skin in fish from Euphrates region with high accumulative concentration of As revealed epidermis (blue row) edematous dermatitis (edema- red row and infiltration of inflammatory cells- black row). $10 * 1.8 x$, Gomori's stain.

These studies revealed low concentrated of essential meals $\mathrm{Zn}, \mathrm{Cu}, \mathrm{Fe}$ in the fish muscle, these metals considered Co-factors for many biological activities. High Levels accumulative concentration of arsenic has been recording in these studies which are agreement with Andreji et al. and ElMoselhy et al. (20,21), arsenic released to aquatic environment through natural sources as weathering, the same result reported by El-Moselhy et al. (19) who refer to high levels concentration accumulation in muscle Catla and Oreochromis spp. In determining the health of fish exposed to pollution, histopathological changes have been commonly used as biomarkers (22) so histopathological changes in the muscle refer to environmental pollution with heavy metals 
or even other toxic materials (23). The result of these study revealed that arsenic accumulative in the fish muscle cause histopathological changes characterized by zenker's necrosis, edematous dermatitis and lymphocytic dermatitis this result is in line with the study of Kaur et al. (24) sever histopathological changes and cellular alteration were observed in muscle and other organs of Cyprinus carpio inhabits in contaminant environment with heavy meatls. Similar alterations in muscles were observed in Oreochromis niloticus fish exposed to heavy metals (25).This pathological alteration is due to the ability of heavy metals to depletion of thiol status plus impaired antioxidant defense system and led to produce oxidative stress which cause oxidized nucleic acids, protein oxidation and lipid peroxidation which affected cell membrane permeability and disturbances in $\mathrm{Na}^{+} / \mathrm{K}^{+}$-ATPase pump and cause vacuolar degeneration with continuous exposure to toxic levels causes zenker's necrosis will be happened as a late stage of degeneration $(26,27)$.

The inter-metals correlation was determined in this study, the result exhibit there was positive correlation between $\mathrm{Zn}$ $\mathrm{Cu}$ also between $\mathrm{Zn}-\mathrm{Pb}$, that mean that metals have biogeochemical pathways in the fish tissue (28) while negative correlation among heavy metals were found for arsenic with both $-\mathrm{Zn}$ and $-\mathrm{Pb}$, these result do not agreement with the result of Rakocevic et al. (29) who reported the positive correlation between $\mathrm{As}-\mathrm{Cu}$ and in contrast negative correlation between $\mathrm{Zn}-\mathrm{Cu}$ in many fish species. These variable results may be due to environmental factors, season, water column component and present other toxic materials which may be forming new chemical compound, or may due to fish health and physiological status, age, size, fish species, diet and food additive or even usage drug and chemical therapy may be affected metabolic, biotransformation pathway of metals in the fish body.

\section{Conclusions}

It is concluded from this study that pollutants and toxic metals have different concentrations in the aquatic environment depending on the geographical distribution. Heavy metals are concentrated in fish muscles which lead to histopathological changes which is the main source of human consumption so these accumulative of toxic heavy metals may affect the public health of humans. Also, there may be inter-relationships (positively and negatively) between the heavy metals.

\section{Acknowledgments}

Great thankfully for everyone who contributed to complete this research.

\section{Conflict of Interest}

No conflict of interest.

\section{References}

1. Troell M, Naylor RL, Metian M, Baveridge M, Tyedmers PH, Folke C, Arrow K, Barrett S, Crepin A, Ehrlich P, Gren A, Kautsky N, Levin S, Nyborg K, Osterblom H, Polasky S, Scheffer M, Walker B, Xepapadeas $\mathrm{T}$, Zeeuw A. Does aquaculture add resilienc to the global food system? proceeding of National Academic Science. 2014;111(37): 1325713263. DOI:org/10.1073/pnas1404067111.

2. Edun OM, Alon R, Panpinit P, Dokubo T, Nweke F, Ogolo C. Effects of water quality of the Boguwa Creek on tilapia culture .Journal of Fisheries and Aquatic Science. 2014;9(6): 463467.DOI:org/10.3923/jfas.

3. Ismail RH, Al-Hamdani AH. Effect of probiotic (Poultrystar ${ }^{\circledR}$ ) and heat stress on some blood parameters in common carp (Cyprinus carpio L.). Iraqi Journal of Veterinary Sciences. 2019; 33(2):221-225. http://www.vetmedmosul.com.

4. Olsvik PA, Gundersen P, Andersen RA, Zachariassen K. Metal accumulation and metallothionein in two populations of brown trout, Salmo trutta, exposed to different natural water environments during a run-off episode. Aquatic Toxicology. 2019; 50: 301-316. DOI:org/10.1016/s0166-445x (00)000941.

5. Pandey S, Parvez S, Ansari R, Ali M, Kaur M, Hayat F, Ahmad F, Raisuddin S. Effects of exposure to multiple trace metals on Biochemical, histological and ultrastructural features of gills of a freshwater fish, Channa punctata Bioch.Chem. Biol.Inter. 2008;174:183-192. DOI: org/10.1016/j.obi.

6. Antal L, Halasi-Kovács B, Nagy1 SA. Changes in Fish Assemblage in The Hungarian section of River Szamos/Someş after a massive cyanide and heavy metal pollution. North-Western Journal of Zoology. 2013;9 (1): 131-138. DOI: org/10.1016/j.rewh4/000660011.

7. Aboua BR, Kouamélan EP, N'Douba V. Development of a fish-based index of biotic integrity (FIBI) to assess the quality of Bandama River in Côte d'Ivoire. Knowledge and Management of Aquatic Ecosystems. 2012; 404(08): 1-19. DOI:org/10.1051/kmae/2012002.

8. Miandare H, Niknejad M, Shabani A, Safari R. Exposure of Persian sturgeon (Acipenser persicus) to cadmium results in biochemical, histological and transcriptional alterations. Comparative Biochemistry and Physiology. 2016; 181: 1-8. DOI: org/10.1061/j.cbpc.

9. Engin MS. The assessment of trace metals at gill, muscle and liver tissue in Mugil cephalus. Environmental Monitoring and Assessment. 2015; 187: 255. DOI:org/10.4314/sokjvs. v15i1.8.

10. Abalaka SA. Histopathological evaluation of Oreochromis mossambicus gills and liver as biomarkers of earthen pond water pollution. Sokoto Journal of Veterinary Sciences.2017; 15(1): 57-66. DOI:org/10.1016/j. rfg4453/00199.

11. AL-Taee SK. Pathological Study of Expermintal Cadmium Toxicity in Common Carp Fishes (Cyprinus carpio L.).M.Sc. Thesis, Veterinary Pathology. University of Mosul-Iraq. 2007.

12. Al-Naemi1 HS, Al-Sanjary RA, Faraj RA, Saadi A. Detection of lead, chromium and cobalt in meats of cattle and buffalo from retails of Mosul city. Iraqi Journal of Veterinary Sciences.2020;34(2):447451.DOI: 10.33899/ijvs.2019.126069.1224.

13. Lucky $Z$. The diagnosis of bacterial disease by infection experiments. In Hoffman GL. ${ }^{2}$ ed. methods for diagnosis of fish disease,Amerind New Delhi. 1977; p40.

14. Luna LG. Manual of Histological Staining Methods of the Armed Forces Institute of Pathology. 1968;McGraw-Hill Book Company.

15. Lamphere DN, Dorn CR, Reddy CS, Meyer AW. Reduced cadmium body burden in cadmium exposed calved fed supplemental Zinc. Environ. Res. 1984;33:119-129. DOI:org/10.1016/00139351(84)90013-6.

16. EPA - Environmental Protection Agency. Aquatic biodiversity. 2009; https://www.epa.ie/newsandevents/news/2009/

17. Kamaruzzaman BY, Rina Z, Akbar john B, Jalal KCA. Heavy metals accumulation in commercially important fishes of south west Malaysian coast. Research Journal of Environmental Sciences. 2011; 5(6): 595-602. DOI:org/10.3923/rjes. 
18. Curlik J, Matusova L. Natural and Man-induced Factors of Soil Pollution. Mitt D Osterr Bodenkundlichen Gesellschaft. 1994; 50:4360. DOI:org/10.1016/j.000976001.

19. Turkmen M, Turkmen A, Tepe Y, Tore Y, Ates A. Determination of metals in fish species from Aegean and Mediterranean Sea. Food chemistry. 2009;113: 233-237. DOI: org/10.1016/j.foodchem.

20. Andreji J, Stranai I, Massanyi P, Valent M. Accumulation of Some Metals in Muscles of Five Fish Species from Lower Nitra River. Journal of Environmental Science and Health Part A. 2006; 41:2607-2622. DOI: $10.1080 / 10934520600928003$.

21. El-Moselhy Kh, Othman A, Abd El-Azem H, El-Metwally MEA. Bioaccumulation of heavy metals in some tissues of fish in the Red Sea, Egypt. Egyptian Journal of basic and applied sciences. 2014; 1: 97 105. DOI: org/101016/j.ejbas.06.001.

22. Abd EL-Salam SS, Ghaly MF, Baraka DM, Mahmoud El-Makhzangy AA. Histopathological changes in diseased and treated catfish(Clarais gariepinus) by ciprofloxacin and clove oil. Iraqi Journal of Veterinary Sciences. 2018; 32(1): 13-19. http://www.vetmedmosul.com

23. Koca YB, Koca S, Yildiz S, Gurcu B, Osanc E, Tuncbas O, Aksoy G. Investigation of histopathological and cytogenetic effects on Lepomis gibbosus (Pices: Perciformes) in the Cine stream (Aydin/Turkey) with determination of water pollution. Environmental Toxicology. 2005;20(6):560-571. DOI: org/10.1002 /tox.20145.

24. Kaur S, Khera KS, Kondal JK. Heavy metal induced histopathological alterations in liver, muscle and kidney of freshwater cyprinid, Labeo rohita (Hamilton). Journal of Entomology and Zoology. 2018;6(2):2137-2144.

http://www.entomoljournal.com/archives/2018/vol6issue2/PartW/6-1372-151.pdf

25. Kaoud HA, El-Dahshan AR. Bioaccumulation and Histopathological alteration of the heavy metals in Oreochromis Nilotic us fish.Nature and Sceince. 2010;8(4).http://www.sceincepub.net/nature.

26. Engwa GA, Ferdinand PU, Nwalo FN, Unachukwu MN. Mechanism and Health Effects of Heavy Metal Toxicity in Humans. 2019; IntechOpen DOI:org/10.5772/intechopen.82511

27. McGavin MD, Zackary JF. Pathologic Basis of Veterinary Disease, ${ }^{4 t h}$ ed. Mosby Elsevier, China. 2007.

28. Jezierska B, Witeska M. Metal toxicity of fish. Wydawnictwo Akademi Podlaskiej, Siedlce. 2001; 318 pp

29. Rakocevic J, Sukovic D, Maric D. Distributaion and Relationships of Eleven Trace Elements in Muscle of Six Fish Species fron Skadar Lake (Montenegro). Turkish Journal of Fisheries and Aquatic Sciences. 2018;18: 647-657. DOI: 10.4194/1303-2712-v18-5-01.
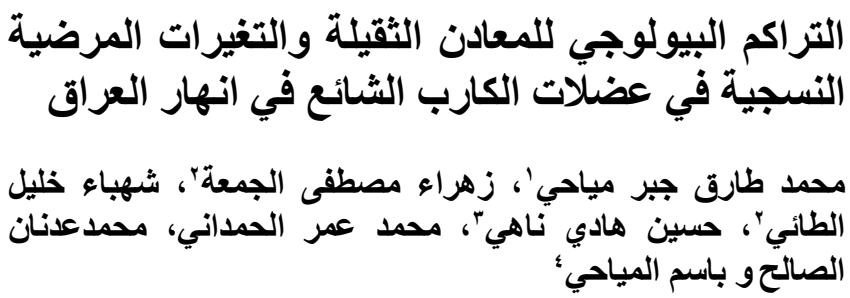

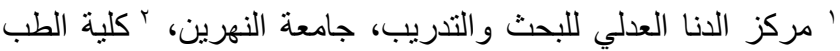

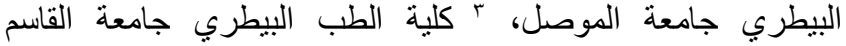

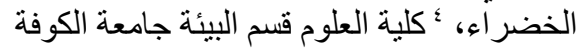

الخلاصة

هدفت هذه الدراسة إلى تقييم حالة التلوث في الأنهار العر اقية شمال

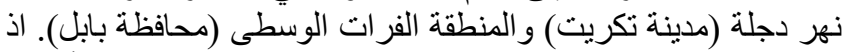

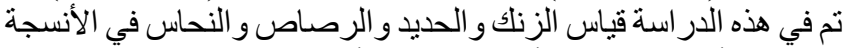

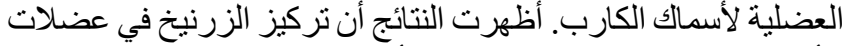

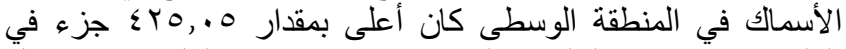

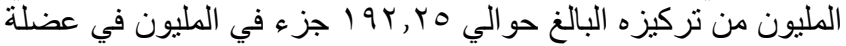
الأسمالك في نهر دجلة ذات دلالة إحصائية. والذي الذي أدى الى الى الى حدوث

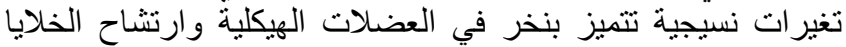

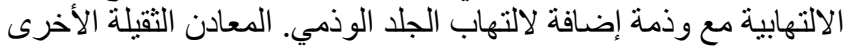

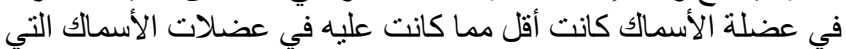

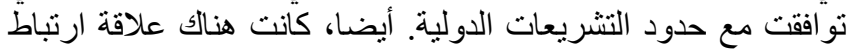

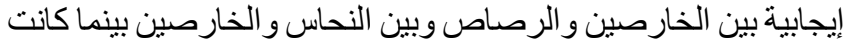
هنالك علاقة سلبية بين الزرنيخ وكلا من (الرصاصن) و و(الخارصين)

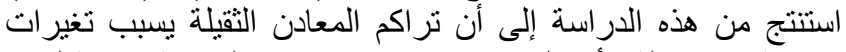

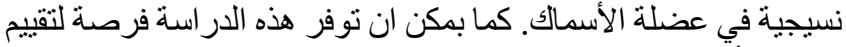
صحة الأسمالك وكذلك معلومات عن المخاطر الصحية المحتملة القادمة فونة

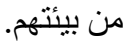

